Notes \& Tips

\title{
Control of pH during plasmid preparation by alkaline lysis of Escherichia coli
}

\author{
Cheri Cloninger, Marilyn Felton ${ }^{1}$, Bonnie Paul ${ }^{1}$, Yasuko Hirakawa, Stan Metzenberg * \\ Department of Biology, California State University, Northridge, Northridge, CA 91330, USA
}

\section{A R T I C L E I N F O}

\section{Article history:}

Received 9 March 2008

Available online 11 April 2008

\begin{abstract}
A B S T R A C T
Alkaline lysis of Escherichia coli is usually the method of choice for plasmid preparation, but "ghost bands" of denatured supercoiled DNA can result if the $\mathrm{pH}$ is too high or the period of lysis is too long. By replacing the usual sodium hydroxide lysis solution with an arginine buffer prepared in the range of $\mathrm{pH} 11.4$ to 12.0, we were able to stabilize the $\mathrm{pH}$ during lysis and obtain plasmid that is suitably pure for restriction digestion and DNA sequencing.
\end{abstract}

(c) 2008 Elsevier Inc. All rights reserved.
The extraction of plasmids from Escherichia coli is one of the most commonly used methods in molecular biology, and detergent lysis of cells in $0.1 \mathrm{M}$ sodium hydroxide $\left(\mathrm{NaOH}^{2}{ }^{2}\right.$ final) is the most widespread approach $[1,2]$. The alkalinity denatures the chromosomal DNA, and the supercoiled plasmid DNA remains intact provided that the $\mathrm{pH}$ does not exceed a threshold of approximately 12.3 [3,4]. However, the $\mathrm{pH}$ of the lysis solution is approximately 12.8 in the absence of cells, and so it is important that biological macromolecules released into the crude lysate provide acid equivalents that partially neutralize and reduce the $\mathrm{pH}$ below the threshold. Without any external buffering during lysis, the reproducibility of the method depends on having enough cell mass to counteract a given volume of $\mathrm{NaOH}$ solution. "Ghost bands" representing irreversibly denatured plasmid have been reported in the literature [5-8] and in technical brochures [9] and appear to develop if the $\mathrm{pH}$ or length of exposure is excessive. We have investigated the effects of varying the $\mathrm{pH}$ during alkaline plasmid extraction using l-arginine as a buffer and found that a lysis solution buffered with arginine can replace the $\mathrm{NaOH}$-based lysis solution of the usual Birnboim-Doly alkaline lysis method [1]. This modification allows comparable plasmid yield under reproducible $\mathrm{pH}$ conditions and prevents the generation of irreversibly denatured supercoiled DNA.

The optimal protocol is described below, with all steps being conducted at room temperature:

1. The cells are collected by centrifugation at $1100 \mathrm{~g}$ for $15 \mathrm{~min}$ and resuspended in $1 / 10$ volume of $10 \mathrm{mM} \mathrm{Tris-Cl}$ and $10 \mathrm{mM}$ ethylenediaminetetraacetic acid (EDTA, pH 8.0).

\footnotetext{
* Corresponding author. Fax: +1 8186772034.

E-mail address: stan.metzenberg@csun.edu (S. Metzenberg).

1 Current address: Department of Natural Science, Los Angeles Mission College, Sylmar, CA 91342, USA.

${ }^{2}$ Abbreviations used: $\mathrm{NaOH}$, sodium hydroxide; EDTA, ethylenediaminetetraacetic acid; SDS, sodium dodecyl sulfate; LB, Luria-Bertani.
}

2. To each $1 \mathrm{ml}$ of cell suspension, $1 \mathrm{ml}$ of a lysis solution consisting of $1 \%(\mathrm{w} / \mathrm{v})$ sodium dodecyl sulfate (SDS) and $0.5 \mathrm{M} \mathrm{L-argi-}$ nine ( $\mathrm{pH} \mathrm{11.7)} \mathrm{is} \mathrm{added,} \mathrm{and} \mathrm{the} \mathrm{tube} \mathrm{is} \mathrm{capped} \mathrm{and} \mathrm{rocked}$ briefly to mix. The lysate is allowed to sit undisturbed for $5 \mathrm{~min}$.

3. The lysate is neutralized by the addition of $1 \mathrm{ml}$ of $5 \mathrm{M}$ potassium acetate ( $\mathrm{pH} 4.75$ ) for each $1 \mathrm{ml}$ of original cell suspension and is rocked again to mix the solutions fully.

4. The lysate is subjected to centrifugation for $10 \mathrm{~min}$ at $20,000 \mathrm{~g}$, and the supernatant is transferred to a clean tube.

5. Isopropanol ( 0.8 volume) is mixed with the supernatant, which is subjected to centrifugation for $10 \mathrm{~min}$ at $20,000 \mathrm{~g}$.

6. The precipitate is washed once with $70 \%(\mathrm{v} / \mathrm{v})$ ethanol, dried in vacuo, and resuspended in $10 \mu \mathrm{l}$ of $10 \mathrm{mM}$ Tris- $\mathrm{Cl}$ and $0.5 \mathrm{mM}$ EDTA ( $\mathrm{pH}$ 8.0) for each $1 \mathrm{ml}$ of starting material.

Fig. 1 shows the DNA and RNA isolated by this procedure from E. coli cells (XL-1 blue strain, Stratagene) grown in Luria-Bertani (LB) medium with $0.05 \mathrm{mg} / \mathrm{ml}$ ampicillin and carrying the plasmid pGEM3Zf+ (Promega). In this experiment, the $\mathrm{pH}$ of the argininebased lysis solution was varied between 11.4 and 13.5, and the plasmid is evident in Fig. 1 as supercoiled and nicked circular bands. The RNA is visible as a smear of staining material below the plasmid bands and is progressively hydrolyzed at higher $\mathrm{pH}$ and with longer incubation periods. The overall plasmid yield does not vary significantly with $\mathrm{pH}$ and is comparable to that obtained by the Birnboim-Doly method [1]; however, slight changes in $\mathrm{pH}$ have a strong effect on whether the plasmid is digestible with a restriction endonuclease (as discussed later).

Extending the lysis period from $5 \mathrm{~min}$ to $24 \mathrm{~h}$ does not eliminate the plasmid, but the gel shows a broad smear of staining material extending from the loading well to the plasmid band in samples incubated above $\mathrm{pH}$ 11.7. The extended period of hydrolysis at high $\mathrm{pH}$ may generate protein and peptidoglycan fragments that are precipitated by the isopropanol treatment, fouling the selective precipitation of nucleic acids and the gel electrophoresis. A lysis buffer with a $\mathrm{pH}$ of 11.4 allows for extended periods of 


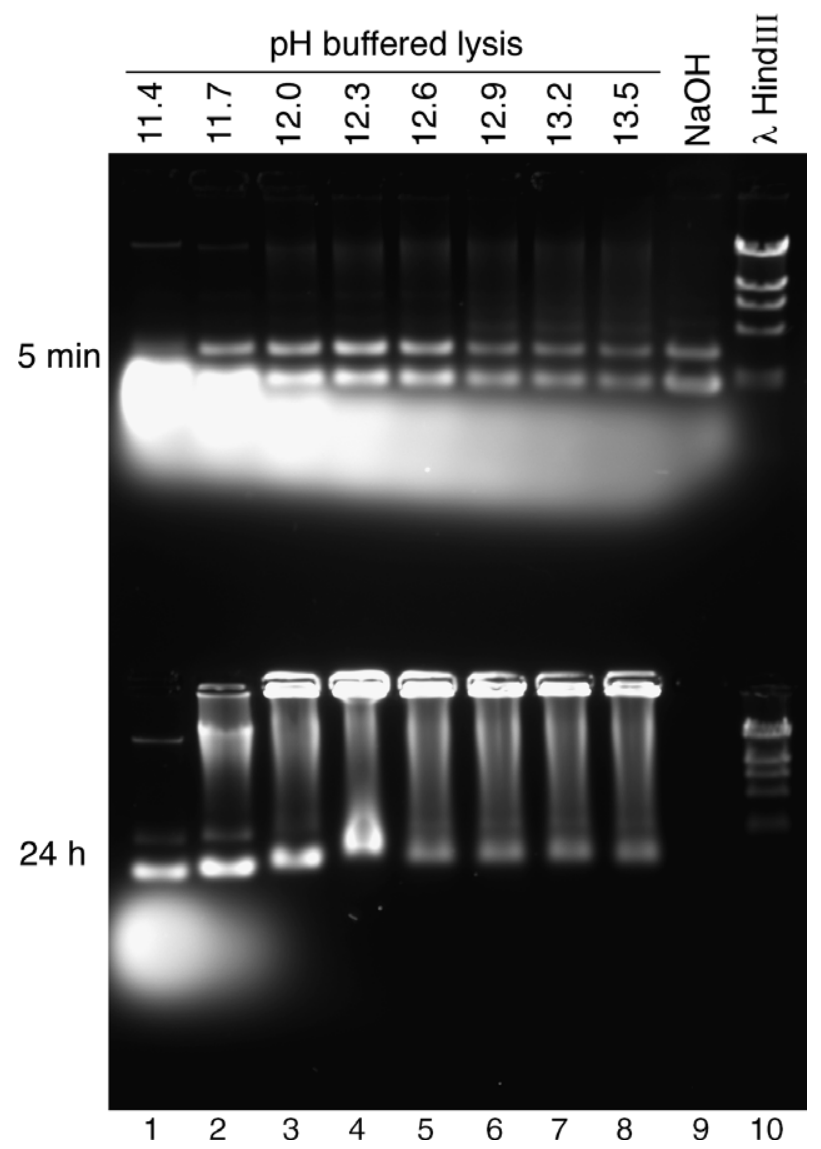

Fig. 1. Gel electrophoresis of pGEM3Zf+ plasmid extracted by alkaline lysis for $5 \mathrm{~min}$ (top half) or $24 \mathrm{~h}$ (bottom half). Lanes 1 to 8 are based on arginine-buffered lysis at the indicated $\mathrm{pH}$. Lane 9 (top half only) is material prepared by the Birnboim-Doly method [1] using unbuffered $\mathrm{NaOH}$. Each lane represents material extracted from $0.1 \mathrm{ml}$ of $E$. coli culture. Lane 10 is $\lambda$ DNA digested with HindIII. The gel was stained with $1 \mu \mathrm{g} / \mathrm{ml}$ ethidium bromide. The $\mathrm{pH}$ values of these lysis buffers were established by mixing a fixed amount of L-arginine with $\mathrm{NaOH}$ to establish zwitterion/anion molar ratios of 12.6 ( $\mathrm{pH} 11.4), 6.31(\mathrm{pH} 11.7), 3.16(\mathrm{pH} 12.0), 1.58$ ( $\mathrm{pH} 12.3), 0.794$ (pH 12.6), 0.398 (12.9), 0.20 (pH 13.2), and 0.10 (pH 13.5) based on a $\mathrm{p} K_{\mathrm{a}}$ of $12.48[10]$.

hydrolysis without this contamination (Fig. 1, lane 1), but this lower pH makes it slightly more difficult to separate the lysate supernatant from the pellet. Sodium acetate and lithium acetate solutions work comparably well to potassium acetate for the neutralization of the lysate provided they are at least $5 \mathrm{M}$ and prepared as an equimolar mixture of acetate salt and acetic acid.

The plasmids prepared by lysis between $\mathrm{pH} 11.4$ and $\mathrm{pH}$ 12.0 are readily digested with EcoRI (Fig. 2), and they are sufficiently pure to use in DNA sequencing, yielding more than 700 bases of readable sequence on an ABI 3130 automated DNA sequencer (Applied Biosystems) (data not shown). Plasmids collected by lysis at a $\mathrm{pH}$ greater than 12.3 are not completely digested by EcoRI, suggesting that the plasmid is either partially denatured or copurifying with inhibiting molecules released by hydrolysis.

Using arginine to control the $\mathrm{pH}$ during lysis provides important advantages. First, the extraction is made more reliable because the buffering compensates for variations in the amount of cell mass extracted per milliliter of lysis solution. Second, the method is less time sensitive because the plasmid is not exposed to a threshold $\mathrm{pH}$ that causes irreversible denaturation. The addition of arginine increases the cost of the lysis solution by less than 2 cents per milliliter and does not interfere with the use of silica-based DNA adsorbents to purify the DNA from the lysate (e.g., Wizard Plus MiniPreps DNA Purification System, Promega).

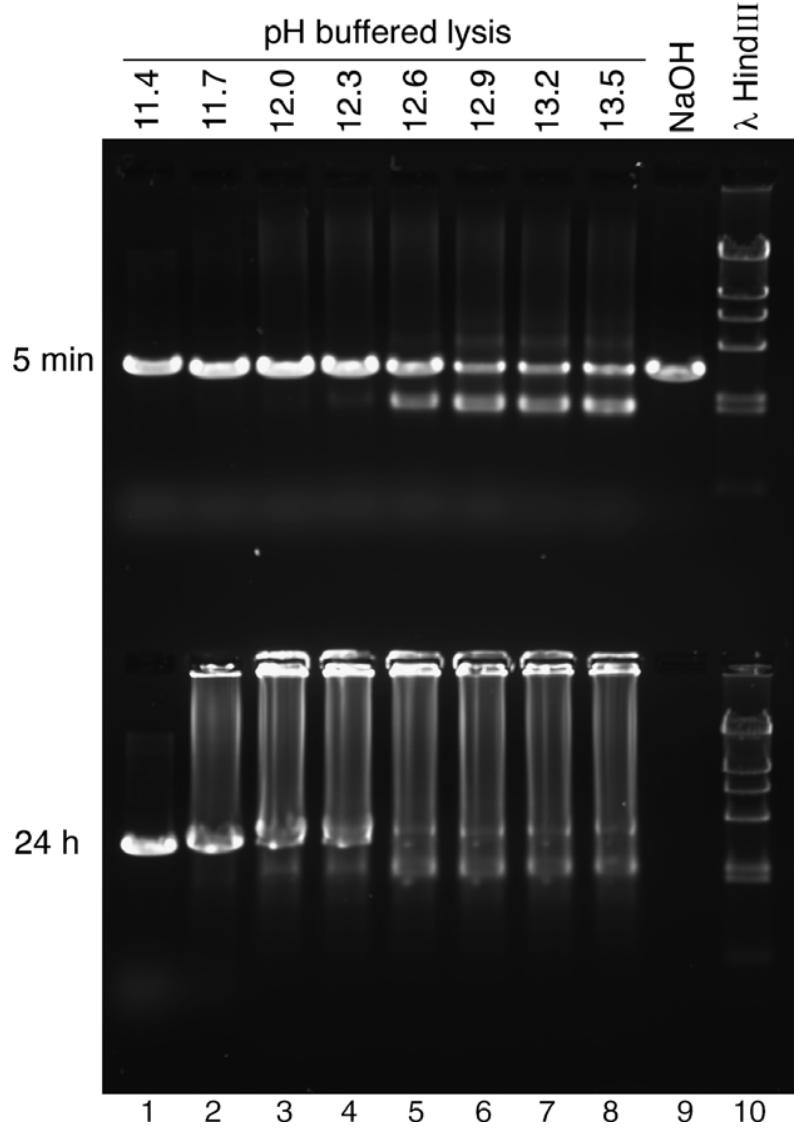

Fig. 2. Gel electrophoresis of pGEM3Zf+ plasmid extracted by alkaline lysis for 5 min (top half) or $24 \mathrm{~h}$ (bottom half) and digested with EcoRI and RNase A. Lanes 1 to 8 are based on arginine-buffered lysis at the indicated $\mathrm{pH}$. Lane 9 (top half only) is material prepared by the Birnboim-Doly method [1] using unbuffered $\mathrm{NaOH}$. Each lane represents material extracted from $0.1 \mathrm{ml}$ of $E$. coli culture and digested with $0.15 \mathrm{U} / \mu \mathrm{l}$ of EcoRI and $0.05 \mathrm{mg} / \mathrm{ml}$ RNase A for $1 \mathrm{~h}$. Lane 10 is $\lambda$ DNA digested with HindIII. The gel was stained with $1 \mu \mathrm{g} / \mathrm{ml}$ ethidium bromide.

\section{Acknowledgments}

Funding for this research was provided by the Office of Research and Sponsored Projects, California State University, Northridge. B.P. and M.F. were supported by Project TRAILS at Los Angeles Mission College. We thank Robert L. Metzenberg for helpful discussions.

\section{References}

[1] H.C. Birnboim, J. Doly, A rapid alkaline extraction procedure for screening recombinant plasmid DNA, Nucleic Acids Res. 7 (1979) 1513-1523.

[2] E.H. Chowdhury, T. Akaike, Rapid isolation of high quality multimeric plasmid DNA using zwitterionic detergent, J. Biotechnol. 119 (2005) 343-347.

[3] J. Vinograd, J. Lebowitz, Physical and topological properties of circular DNA, J. Gen. Physiol. 49 (2005) 103-125.

[4] T.C. Currier, E.W. Nester, Isolation of covalently closed circular DNA of high molecular weight from bacteria, Anal. Biochem. 76 (1976) 431-441.

[5] J.M. Ranhand, The enrichment of plasmid DNAs, in bacterial cell lysates, using an alkaline-pH procedure that does not permanently denature them, Prep. Biochem. 15 (1985) 121-131.

[6] P.N. Hengen, Methods and reagents: Ghost plasmid of pBluescript, Trends Biochem. Sci. 19 (1994) 139-140.

[7] P.N. Hengen, Methods and reagents: Eliminating ghost bands from plasmid preps, Trends Biochem. Sci. 21 (1996) 441-442.

[8] J.R. Sayers, D. Evans, J.B. Thomson, Identification and eradication of a denatured DNA isolated during alkaline lysis-based plasmid purification procedures, Anal. Biochem. 241 (1996) 186-189.

[9] Qiagen, Qiagen Plasmid Purification Handbook, 3rd ed., Qiagen, Valencia, CA, 2005. (http://www1.qiagen.com/HB/PlasmidPurification).

[10] D.R. Lide, CRC Handbook of Chemistry and Physics, 71st ed., CRC Press, Boca Raton, FL, 1990. p. 7-1. 